IZA DP No. 8489

The Impact of a One Laptop per Child Program on Learning: Evidence from Uruguay

Gioia de Melo

Alina Machado

Alfonso Miranda

September 2014 


\title{
The Impact of a One Laptop per Child Program on Learning: Evidence from Uruguay
}

\author{
Gioia de Melo \\ Universidad de la República \\ and Banco de México \\ Alina Machado \\ Universidad de la República \\ Alfonso Miranda \\ and $I Z A$ \\ Discussion Paper No. 8489 \\ September 2014 \\ IZA \\ P.O. Box 7240 \\ 53072 Bonn \\ Germany \\ Phone: +49-228-3894-0 \\ Fax: +49-228-3894-180 \\ E-mail: iza@iza.org
}

Center for Research and Teaching of Economics (CIDE)

\begin{abstract}
Any opinions expressed here are those of the author(s) and not those of IZA. Research published in this series may include views on policy, but the institute itself takes no institutional policy positions. The IZA research network is committed to the IZA Guiding Principles of Research Integrity.

The Institute for the Study of Labor (IZA) in Bonn is a local and virtual international research center and a place of communication between science, politics and business. IZA is an independent nonprofit organization supported by Deutsche Post Foundation. The center is associated with the University of Bonn and offers a stimulating research environment through its international network, workshops and conferences, data service, project support, research visits and doctoral program. IZA engages in (i) original and internationally competitive research in all fields of labor economics, (ii) development of policy concepts, and (iii) dissemination of research results and concepts to the interested public.
\end{abstract}

IZA Discussion Papers often represent preliminary work and are circulated to encourage discussion. Citation of such a paper should account for its provisional character. A revised version may be available directly from the author. 


\section{ABSTRACT \\ The Impact of a One Laptop per Child Program on Learning: Evidence from Uruguay ${ }^{\uparrow}$}

We present evidence on the impact on students' math and reading scores of one of the largest deployments of an OLPC program and the only one implemented at a national scale: Plan Ceibal in Uruguay. Unlike previous work in the field, we have unique data that allow us to know the exact date of laptop delivery for every student in the sample. This gives us the ability to use a continuous treatment, where days of exposure are used as a treatment intensity measure. We use a difference-in difference strategy including fixed effects at the individual level. Given that there is some variation in the date of laptop delivery across individuals within the same school, we can identify the effect of the program net of potential heterogeneity in the rate schools gain improvements on student's achievement over time in the absence of the OLPC program across the country (i.e. we allow each school to follow a different learning growth curve over time due to unobservable time-varying heterogeneity). We also run an alternative specification where we allow for different learning growth curves over time between schools located in Montevideo and the rest of Uruguay. Our results suggest that in the first two years of its implementation the program had no effects on math and reading scores. The zero effect could be explained by the fact that the program did not involve compulsory teacher training and that laptops in class are mainly used to search for information on the internet.

JEL Classification: $\quad$ I21, I28

Keywords: technology, education, impact evaluation

Corresponding author:

Gioia de Melo

Economic Research Department

Bank of Mexico

5 de Mayo 18, CP 06059

Mexico City

Mexico

E-mail: gdemelo@banxico.org.mx

\footnotetext{
${ }^{1}$ This project was funded by a research grant from Centro Ceibal, as well as by the Administración Nacional de Educación Pública (ANEP). It would not have been possible without the cooperation of the Research Evaluation and Statistics Division, (DIEE, ANEP) and the administrative records Centro Ceibal provided us with. We are particularly grateful for advice received from Julián Cristia. We also would like to specially thank for the cooperation of researchers from the Economics Institute (Universidad de la Republica), Rodigo Arim (dean of the Economics Faculty, Universidad de la República), Andrés Peri and Alejandro Retamoso (DIEE, ANEP), and Cecilia Marconi and Gonzalo Graña from Centro Ceibal as well as comments received by Yu Zhu.
} 


\section{Introduction}

In recent years many countries have made substantial investments in One Laptop per Child (OLPC) programs, while others are about to start implementing this type of interventions. This paper contributes to the study of the effect of OLPC programs on students reading and math scores using a quasi-experimental design and data from Uruguay, the first country to implement a OLPC program at a national scale (Plan Ceibal) and currently one of the largest deployments with one million laptops delivered. ${ }^{2}$

Although relatively abundant, the literature on the effects of the use of computers on educational outcomes is still mixed. Fairlie and Robinson (2013) find that the use of computers at home has no effect on children's educational outcomes, while Vigdor and Ladd (2010) and Malamud and Pop-Eleches (2011) report a negative effect. Similarly, studying the impact of computers at school, Angrist and Lavy (2002) find a negative impact, while Machin et al. (2007) find the contrary.

Banerjee et al. (2007) concentrate on the impact of specific software on math and find a substantial positive effect. Unfortunately, the effect is short-lived and disappears within a year of the end of treatment. Carrillo et al. (2010) evaluate a project that provides computer-aided instruction in math and reading and find a positive effect in math and no effect in reading. By means of a randomized controlled trial evaluation Mo et al. (2013) analyze the impact of an intervention in 13 migrant schools of Beijing. The intervention involved the distribution of laptops with learning/remedial software installed, plus a single training session on the use of the computer. No training to teachers as to how to use computers to improve the learning/teaching process was provided. The authors find a positive effect on math (only significant at the 10\% level) but no effect on reading.

So far, the evidence in the field of OLPC impact evaluation comes from only one study implemented in Peru. Cristia et al. (2012) report results from a large-scale randomized control trial (RCT) evaluation of an OLPC program in 319 public schools in small and poor communities of rural Peru. Most treated schools had no access to internet and the distribution of laptops was not coupled with training to teachers on how they may use computers to improve teaching and learning. Treatment and controls were followed for 15 months. The authors find no effect on either math or reading, though some statistically significant impact on cognitive skills, as measured by a Raven’s Progressive Matrices test, was detected. ${ }^{3}$

Unlike the study by Cristia et al. (2012), our study is not particularly targeted to evaluate the impact of the OLPC program in the context of rural schools in poor communities. Instead, our evaluation survey delivers a representative sample of all schools in Uruguay, both rural and urban. We use a difference-in-difference strategy (DiD) to estimate the impact of Plan Ceibal on educational achievement. The analysis exploits the fact that the rollover of the program was

\footnotetext{
${ }^{2}$ Public primary school students and teachers (and more recently junior high students) were provided with a laptop and internet access. By October 2013, Plan Ceibal had distributed one million laptops. This figure is larger than the number of beneficiaries because XOs are exchanged for more powerful laptops when students reach junior high.

${ }^{3}$ There is a second study on Nepal not currently available online (Sharma, 2012). This study uses a DiD estimator applying a quasi-experimental design and reports a negative effect on reading but no effect on math.
} 
based on geographic criteria and not on students' school performance. The precise information of the date in which each student received the laptop is available. Thereby, the treatment is measured as the number of days that each student has been exposed to the program by the time of the follow-up date (normalized to years). Given that there is some within-school variation in hand-in dates, we are able to control, keeping an individual fixed-effects framework, for potential heterogeneity in the rate schools gain improvements on student's achievement over time in the absence of the OLPC program (i.e. we allow each school to follow a different learning growth curve over time due to unobservable time-varying heterogeneity). As the withinschool variation in laptops hand-in dates is not large, we run alternative specifications controlling for potential systematic differences in school improvement over time between schools in Montevideo (the capital of Uruguay) and the rest of Uruguay.

Our main estimates are based on a panel of students first contacted in October 2006 when they attended third grade in primary school and subsequently followed-up in October 2009, when most of them were attending sixth grade (i.e. final year of primary school). By the end of 2009, all primary school students had received their laptops but while some had been exposed to the program for almost two years, others had been treated for less than a month. This variation in the intensity of treatment is what allows us to identify the causal effect of the Ceibal program on children's scores, net of observable and unobservable individual characteristics and controlling for potential systematic differences in school achievement improvement over time across schools or across regions. Findings suggest the program had no impact on either reading or math scores. These findings also hold if the within-school treatment variation is discarded and the impact of the program is estimated analyzing a panel of schools that exploits only the between-school treatment variation and allows exclusively for heterogeneity in the learning growth curve of Montevideo and the rest of Uruguay in the absence of the OLPC program.

The rest of the paper is organized as follows. Section 2 describes the program and data. Section 3 discusses the identification strategy. Section 4 reports results. Finally, Section 5 concludes. Tables are included in the Annex.

\section{Data and background information}

\subsection{OLPC program in Uruguay: Plan Ceibal}

Plan Ceibal's key objective is to promote digital inclusion among Uruguayan children. ${ }^{4}$ It also intends to improve learning both at school and at home. ${ }^{5}$ Public primary school students and teachers (and more recently junior high students) are provided with a laptop and internet access. ${ }^{6}$ Students who were granted a laptop (XO) while in primary school are encouraged to exchange it for standard laptops during junior high. ${ }^{7}$ By October 2013, Plan Ceibal had distributed one million laptops and had benefitted approximately 625,000 students with an estimated cost of 180

\footnotetext{
${ }^{4}$ Ceibal stands for: Conectividad Educativa de Informática Básica para el Aprendizaje en Línea.

${ }^{5}$ Presidential decrees April $18^{\text {th }} 2007$ and December $15^{\text {th }} 2008$.

${ }^{6}$ Public education is widespread. Approximately $80 \%$ of primary school children attend public schools.

${ }^{7} \mathrm{XO}$ is a type of laptop used by OLPC programs.
} 
dollars per laptop. ${ }^{8}$ The number of laptops distributed is larger than the number of beneficiaries because XOs are exchanged for more powerful laptops when students reach junior high.

The project provides schools and other areas such as public squares with wireless internet connection. Students take the laptops home and can often access internet either through the school's or through other public places' signal. The software installed in laptops contains: standard programs to write, make calculations, programming environment (Tortugarte, Etoys, Scratch, Pippy), browse the web (Navegar), draw and design (Tuxpaint, Pintar), study geography (Geo gebra/ Dr. Geo, Conozco Uruguay), take photos and make videos, produce and edit sounds (Tam tam mini, Sara), learn English (English for fun), play games (Laberinto), as well as books.

The initiative was launched in a pilot province in 2007. ${ }^{9}$ During the first semester of 2008 laptops were distributed mostly in schools in the western provinces and in the eastern provinces during the second semester of 2008, reaching Montevideo and Canelones (a province nearby Montevideo) in 2009. By October 2009, all students and teachers in public primary school had been granted a laptop (UNESCO, 2011, p.34). The government decided to begin distributing laptops in the rest of the provinces and end up in the capital, Montevideo, in order to shift the focus which has always favored centralism (Balaguer, 2010).

It should be noted that Ceibal is an institution that reports directly to the President. As such, it is not part of the Administración Nacional de Educación Pública (ANEP), the central authority responsible for education in Uruguay. While this feature speeded the implementation of the program, it also implied that the coordination with teachers has not been as fluent as it would have been desired. Right from the start, there were optional courses available for teachers (both in-person and online). Training was only compulsory for school inspectors and teachers who applied as external consultants to support schools in the process of incorporation of laptops in the teaching process (Maestros Dinamizadores). ${ }^{10}$ Plan Ceibal did not entail formal parental involvement until 2012. Since then on, some schools that were assigned a Ceibal Support Teacher (Maestro de Apoyo Ceibal), organized workshops involving relatives and people that live in the neighborhood who are interested in learning how to use the laptop. These workshops have been implemented in very few schools so far.

The data set we analyze includes a survey among students, family, teachers and school principals regarding Plan Ceibal which was carried out in October 2009. According to this survey, by 2009 $87 \%$ of school principals had internet access at school but connectivity did not allow every grade in a school to connect simultaneously. In fact, $83 \%$ of school principals argued that less than $50 \%$ of students in a school could connect at the same time. Principals' perceptions of the impact of Ceibal were extremely positive in all aspects, especially as regards the students' motivation to work in class and learning (see Table 1). As for teachers, 59\% answered that they used a computer on a daily basis. Regarding the students surveyed, 65\% of the students' households

\footnotetext{
${ }^{8}$ The number of beneficiaries excludes pre-school students. Laptops are also provided to pre-school students although they do not take them home.

${ }^{9}$ The first province that received laptops by the end of 2007, Florida, was selected because of being situated close to Montevideo.

${ }^{10}$ From 2012 onwards, ANEP created the role of Maestro de Apoyo Ceibal (MAC), assigning a teacher to each school to provide support in terms of technologies of information and communication. Training for this kind of teachers is compulsory.
} 
owned a personal computer or a laptop (other than Ceibal's laptop) and 47\% had internet access either through broadband or through Ceibal's wireless signal. Almost all parents answered that the students used the Ceibal laptop at home and 80\% also used another computer (see Table 2).

\subsection{Data}

We use panel data from students evaluated both in 2006 and 2009. Both waves included math and reading standardized tests together with questionnaires to students, their families, teachers and the schools' principals. The first wave corresponds to the SERCE evaluation (Segundo Estudio Regional Comparativo y Explicativo) designed by UNESCO and implemented in October 2006. ${ }^{11}$ By that time, the students analyzed in this paper were attending third grade. The second wave corresponds to the V Evaluación Nacional de Aprendizajes carried out in October 2009 by ANEP. Both studies are representative at the national level. Among the sample of schools evaluated, ANEP included schools that had participated in the SERCE evaluation in order to build a panel. From 6222 students in public schools that had participated in the SERCE evaluation in October 2006, 2645 also participated in the Evaluación Nacional de Aprendizajes in 2009. By that time, the majority was attending the last year of primary school. Students that had participated in the evaluation in 2006 and had in the meantime repeated a grade (i.e. that were attending $4^{\text {th }}$ or $5^{\text {th }}$ grade), were also evaluated in 2009.

Student identification numbers and full names were available for schools that participated in the October 2009 evaluation. This enabled us to match 92\% of students in public schools who were both evaluated in 2006 and 2009 with the administrative records Plan Ceibal has. The administrative records contain the exact date in which each student received his/her laptop. Within a school, laptops were distributed to most students on the same day and those who were absent on that day received it later. The within-school variation in hand-in dates explains slightly more than $2 \%$ of the total hand-in date variation in our sample. Table 3 shows the distribution of observations matched by geographic location, month and year of receipt.

Table 4 presents descriptive statistics for those students who participated in both evaluations and for whom we have information on the date they received the laptop. Reading and math tests were standardized to mean 0 and standard deviation equal to 1.

\section{Methodology}

The identification strategy exploits the fact that we observe laptop hand-in dates for almost every individual in the panel. Our treatment variable is the number of days exposed to the program, reflecting the intensity of treatment. To facilitate the interpretation, we normalize this variable into years of exposure. We start by estimating the following model:

$Y_{i s t}=X_{i s t} \boldsymbol{\gamma}+\beta T_{i s t}+\delta_{t}+c_{i}+u_{i s t}$

where $Y_{i s t}$ represents the test score of individual $i$ at school $s$ in wave $t ; i=1, \ldots, N, s=1, \ldots, 90$, and $t=2006,2009$. $T_{i s t}$ is the treatment variable that reflects the number of days (in terms of years) the student has had the laptop by $t . X_{i s t}$ are time-varying characteristics, $\delta_{t}$ is a dummy indicator

\footnotetext{
${ }^{11}$ This evaluation was performed in sixteen Latin American countries plus one state in Mexico.
} 
of year 2009, $c_{i}$ are individual fixed effects, and $u_{i s t}$ is the idiosyncratic error term. In all models we considered the explanatory variables to be exogenous. In other words, we assume that the condition $E\left(u_{i s t} \mid X_{i s}, T_{i s t}, \delta_{t}, c_{i}\right)=0$ is met. Also, for every model we report robust standard errors (i.e. we use the White-Huber-Eiker estimator of the covariance matrix) clustered at the school level. The model is fitted by fixed-effects. We work with a balanced panel at the individual level because we only have two waves and are implementing a fixed-effects estimator.

The specification in equation (1) assumes that schools follow a common trend as in the standard differences-in-differences model. However, given that there is some within-school variation in hand-in dates, we relax the common trend assumption and allow for heterogeneity in the rate schools gain improvements on student's achievement over time in the absence of the OLPC program (i.e. we allow each school to follow a different learning growth curve over time due to unobservable time-varying heterogeneity). This strategy allows us to control for potential timevarying heterogeneous shocks to schools - for instance, changes in the school management style over time - that otherwise would be interpreted as part of the Plan Ceibal's treatment effect.

$Y_{i s t}=X_{i s t} \boldsymbol{\gamma}+\beta T_{i s t}+\delta_{t}+\pi_{s} \times \delta_{t}+c_{i}+u_{i s t}$

Equation (2) enables to control for changes in school level time-varying unobserved heterogeneity relative to the baseline period by including interactions between school dummies and the time dummy $\pi_{s} \times \delta_{t}$ (Wooldridge 2002, p. 267). Model (2) is also estimated by individual fixed effects.

However, the within school variation in laptops hand-in dates is not large. Because there is evidence that suggests that there are differential trends over time between Montevideo (the capital) and the rest of Uruguay (see Table 6), we would like to control for the likely event that schools in Montevideo and schools in the rest of Uruguay gain improvements in achievement at different rates in the absence of the OLPC program. In other words, we would like to control for potential time-varying shocks to schools that are different in the capital and the rest of Uruguay:

$Y_{i s t}=X_{i s t} \boldsymbol{\gamma}+\beta T_{i s t}+\delta_{t}+$ Montevideo $\times \delta_{t}+c_{i}+u_{i s t}$

where Montevideo represents a dummy indicating schools located in the capital. Equation (3) enables to control for changes in region level time-varying unobserved heterogeneity relative to the baseline period by including interaction terms between the Montevideo dummy and year 2009. Again, model (3) is estimated by individual fixed effects. Robust standard errors clustered at the school level are reported.

We also implement a robustness check using an estimator that does not exploit the within-school variation of the treatment. Namely, we collapse the data at the school level to form a balanced panel of schools for the years 2006 and 2009. In this specification the dependent and control variables are mean averages at the school level. The estimated model is:

$Y_{s t}=X_{s t} \boldsymbol{\gamma}+\beta T_{s t}+$ Montevideo $\times \delta_{t}+c_{s}+u_{s t}$ 
which is fitted by fixed effects at the school level. Robust standard errors clustered at the school level are reported.

\section{Results}

Table 5 reports results from estimating a fixed effects model at the individual level (Eq. 1 in Section 3) including time-varying regressors. Standard errors are clustered at the school level. Time varying characteristics include: the number of persons living in the house, the number of rooms in the house, access to drinking water, access to durable goods (telephone, cable tv, dvd, microwave, washing machine and dishwasher) and a dummy that indicates whether the child works. Under this model, there seems to be a positive and significant effect in math: one year of exposure to Plan Ceibal would increase math scores in 0.16 standard deviations. However, when we consider only observations from the rest of the country excluding Montevideo, the effect is no longer significant. Note that variation in time of exposure to Ceibal holds even after excluding Montevideo with a maximum of exposure of almost two years and a minimum of almost days as the second test took place in October 2009 (see Table 3).

In fact, Table 5 does not control for potential heterogeneity in the rate schools gain improvements on student's achievement over time in the absence of the OLPC program across the country. To evaluate the existence of pre-existing differences in trajectories among regions we use data from the educational authority (ANEP) on teacher seniority (percentage of teachers with less than 5 years of seniority) for all public schools in Uruguay. We estimate the effect of differential trends by region by including two dummy variables: Montevideox2006 and Montevideox2007, as well as time dummies and school fixed effects. Robust standard errors clustered at the school level are reported. We observe a differential evolution of teacher seniority in Montevideo and the rest of the country during 2007, significant at the 1\% level (see Table 6). This suggests equation 1 should not be estimated without controlling for divergent trajectories among regions. Otherwise, the treatment variable is confounded with the pre-existent differences in learning trajectories across schools.

To address this issue, we then estimate an individual fixed effects model including school-time dummies (Table 7). Under this specification, treatment effects in math are no longer significant. The possibility of including school-time dummies is due to the presence of a $2 \%$ within school treatment variation. However, given that this variation is not large, in the last column of Table 7 we substitute school-time dummies for a Montevideo-time dummy. The results also show that the effect in math is not significant.

We then discard the within-school treatment variation to estimate the impact of the program by collapsing data at the school level (Table 8). When exploiting only the between-school treatment variation and allowing for heterogeneity in the learning growth curves of Montevideo and the rest of Uruguay in the absence of the OLPC program (i.e. including a Montevideo-time dummy), we do not observe any significant impact on reading or math. Also, if we estimate the model excluding Montevideo (thereby without including a Montevideo-time dummy) we do not find a significant effect in math either. 
Finally, we test for heterogeneous effects across children with different mother's education under the main specification in Table 7 (including school-time dummies) and do not find any effects either in reading or math (see Table 9).

Tables 10 and 11 attempt to provide some hints regarding the reason why Plan Ceibal does not seem to have had an impact on reading and math. First, the use of laptops in class is not widespread across all public schools (see Table 10). Second, Table 11 suggests that students use their laptops in class mostly to search information from internet (68\% answered that looking for information in the net is the most frequent use of the laptop in class). ${ }^{12}$ The fact that laptops are used in class mainly to download information suggests that impacts on reading and math should not be expected.

\section{Conclusion}

In this paper, we apply panel data analysis to estimate the impact of Plan Ceibal (a nationwide OLPC program implemented in Uruguay) on reading and math skills. Precise information of the date in which each student received the laptop is available. Given that there is some variation in the date of laptop delivery across individuals within the same school we can identify the effect of the program net of potential heterogeneity in the rate schools gain improvements on student's achievement over time in the absence of the OLPC program (i.e. we allow each school to follow a different learning growth curve over time due to unobservable time-varying heterogeneity). We also run an alternative specification where we allow for different learning growth curves over time between schools located in Montevideo and the rest of Uruguay.

Our findings suggest that the program did not have an impact on reading and math scores. This is in line with most of the literature on the impact of computers on learning, in which either no effects or negative effects are found (Angrist and Lavy 2002; Vigdor and Ladd, 2010; Malamud and Pop-Eleches, 2011; Cristia et al., 2012 and Fairlie and Robinson, 2013). A particularly important feature of the program is that teacher training has been, up to now, optional. Furthermore, when analyzing descriptive data on the frequency of laptop use during class and the tasks for which computers are used in class, we observe that every-day use of laptops in class is not widespread across all public schools. Besides, laptops' main use in class is to search for information in the internet. These characteristics provide a hint on why it is reasonable not to find an effect on these skills.

Both Nesta (2012) and Fullan and Langworthy (2013) highlight that technology cannot impact learning unless the teaching-learning process is transformed. In order to impact learning, technology must no longer be conceived as a tool to gather information, but rather as a tool that radically changes the teaching and learning process. In this context, the role of teachers should no longer be to transmit knowledge but to convey learning attitudes, support peer learning, and help children in converting information into knowledge (Nesta, 2012; Fullan and Langworthy, 2013). Plan Ceibal has taken on board these aims in the last few years, incorporating many

\footnotetext{
12 The fact that a significant percentage of students answer that the main use of the laptop in class is to play games should not be interpreted necessarily as indicating that the laptops cause a distraction for learning, as laptops contain some games developed for educational purposes.
} 
programs that help teachers use the laptop in class. ${ }^{13}$ The students analyzed in this study received their laptops when Plan Ceibal had just started and, thereby, did not benefit from the recent changes in the program while in primary school. In future research it would be particularly interesting to evaluate the impact on learning as well as on other outcomes of the new resources that Ceibal has now made available.

An important clarification is due. The fact that we do not find significant effects of the use of computers on children's reading and math scores does not mean that using a computer for learning at school is futile. Clearly, there may be cognitive skills other than the ones tested in math and reading exams that computers help developing. For instance, other studies have found a positive impact on cognitive skills based on Raven's Progressive Matrices test (Malamud and Pop-Eleches, 2011; Cristia et al., 2012).

\section{References}

Angrist J. and Lavy V. (2002) "New Evidence on Classroom Computers and Pupil Learning”. The Economic Journal, Vol. 112, No. 482, pp. 735-765.

Balaguer, R. (2010). "Plan Ceibal. Los ojos del mundo en el primer modelo OLPC a escala nacional.”

Banerjee, A., Cole, S., Duflo, E. and Linden, L. (2007) Remedying Education: Evidence from Two Randomized Experiments in India. Quarterly Journal of Economics, 122(3), 1235-1264.

Carrillo P., Onofa, M. and Ponce, J. (2010) "Information Technology and Student Achievement: Evidence from a Randomized Experiment in Ecuador”. IDB Working Paper Series No. 223.

Cristia J., Ibarraran P., Cueto S., Santiago A., and Severin E. (2012) “Technology and Child Development: Evidence from the One Laptop per Child Program”. IZA DP No. 6401.

Fairlie, R., Beltran, D., and Das, K. (2010). "Home Computers and Educational Outcomes: Evidence from the NLSY97 and CPS.” Economic Inquiry, 771-792.

Fairlie, R. and Robinson, J. (2013) "Experimental Evidence on the Effects of Home Computers on Academic Achievement among School Children”, NBER 19060.

Ferrando, M., Machado, A., Perazzo, I. and Vernengo, A. (2011) “Aprendiendo con las XO: El impacto del Plan Ceibal en el aprendizaje” Instituto de Economía, Series documentos de trabajo DT 3/11.

Fullan, M. and Langworthy, M. (2013) “Towards a New End: New Pedagogies for Deep Learning”.

\footnotetext{
${ }^{13}$ For instance, as was mentioned before, nowadays each school has a teacher whose role is to support others in the use of the laptop. Also, laptops are now used to perform online tests designed by the education authority. Teachers can immediately access the test questions and results and work on strengthening the identified problems.
} 
Machin, S.; Mc Nally, S. and Silva O. (2007) New Technology in Schools: is there a Payoff? The Economic Journal, 117, pp. 1145-1167.

Malamud, O. and Pop-Eleches C. (2011) "Home Computer Use and the Development of Human Capital”. Quarterly Journal of Economics, 126, 987-1027.

Mo, D.; Swinnen J., Zhang L., Hongmei Y., Qu Q., Boswell M., and Rozelle S. (2013). “Can One-to-One Computing Narrow the Digital Divide and the Educational Gap in China? The Case of Beijing Migrant Schools”, World Development, Vol 46, pp. 14-29.

Mundlak, Y. (1978), “'On the Pooling of Time Series and Cross Section Data,' Econometrica, 46, 69-85.

Nesta (2012) “Decoding Learning: the Proof, Promise and Potential of Digital Education”.

Sharma, U. (2012) "Can Computers Increase Human Capital in Developing Countries? An Evaluation of Nepal’s One Laptop per Child Program” Mimeo.

UNESCO (2011) "Plan CEIBAL in Uruguay. From Pedagogical Reality to an ICT Road Map for the Future."

Vigdor, J. and Ladd H. (2010) "Scaling the Digital Divide: Home Computer Technology and Student Achievement”. NBER Working Paper 16078.

Wooldridge J. (2002) Econometric Analysis of Cross Section and Panel Data, MIT Press, London. 


\section{Appendix}

Table 1. In your opinion, what was the impact of Plan Ceibal in your school? Question asked to school principals.

\begin{tabular}{lcccc}
\hline & Positive & Negative & Did not influence & Don't know \\
\hline Attendance & $31.3 \%$ & & $68.4 \%$ & $0.3 \%$ \\
Students' motivation to work in class & $86.0 \%$ & & $13.0 \%$ & $1.0 \%$ \\
Students' motivation to do homework & $72.4 \%$ & & $18.1 \%$ & $9.5 \%$ \\
Organization of work in class & $60.5 \%$ & $14.1 \%$ & $20.3 \%$ & $5.1 \%$ \\
Behavior & $63.3 \%$ & & $36.1 \%$ & $0.5 \%$ \\
Students' self-esteem & $84.3 \%$ & & $5.9 \%$ & $9.8 \%$ \\
Learning & $85.8 \%$ & & $11.5 \%$ & $2.7 \%$ \\
Teachers'motivation to work in class & $77.1 \%$ & & $20.5 \%$ & $2.5 \%$ \\
Parents' school involvement & $53.6 \%$ & & $46.2 \%$ & $0.2 \%$ \\
\hline
\end{tabular}

Source: V Evaluación Nacional de Aprendizajes, ANEP 2009, weighted.

Table 2. Who uses a computer at home? Question asked to parents.

\begin{tabular}{lcc}
\hline Who uses a computer at home? & & \\
\hline & Ceibal laptop & Another computer \\
\hline The student being evaluated & $97.3 \%$ & $79.7 \%$ \\
His/her younger siblings who do not have their own Ceibal laptop & $30.2 \%$ & $36.2 \%$ \\
His/her older siblings who do not have their own Ceibal laptop & $33.6 \%$ & $56.6 \%$ \\
His/her mother & $40.5 \%$ & $70.3 \%$ \\
His/her father & $23.8 \%$ & $56.0 \%$ \\
Others & $13.5 \%$ & $24.2 \%$ \\
\hline
\end{tabular}

Source: V Evaluación Nacional de Aprendizajes, ANEP 2009, weighted. 
Table 3. Percentage of students by date of laptop receipt and geographic area

\begin{tabular}{|c|c|c|c|c|c|c|}
\hline & \multicolumn{3}{|c|}{ Rest of the country } & \multicolumn{3}{|c|}{ Montevideo } \\
\hline & 2007 & 2008 & 2009 & 2007 & 2008 & 2009 \\
\hline January & & $0.35 \%$ & & & & \\
\hline February & & & & & & \\
\hline March & & & $0.04 \%$ & & & \\
\hline April & & $3.73 \%$ & $9.91 \%$ & & $0.04 \%$ & \\
\hline May & & $7.94 \%$ & $5.03 \%$ & & & \\
\hline June & & $9.03 \%$ & $0.18 \%$ & & & $7.52 \%$ \\
\hline July & & $2.85 \%$ & & & & $11.21 \%$ \\
\hline August & & $0.00 \%$ & $0.11 \%$ & & $4.29 \%$ & $13.15 \%$ \\
\hline September & & $3.20 \%$ & $0.11 \%$ & & $0.04 \%$ & $8.05 \%$ \\
\hline October & & $4.18 \%$ & $0.04 \%$ & & & $0.14 \%$ \\
\hline November & & $4.89 \%$ & & & & \\
\hline December & $3.90 \%$ & $0.11 \%$ & & & & \\
\hline Total & $3.90 \%$ & $36.27 \%$ & $15.40 \%$ & & $4.36 \%$ & $40.07 \%$ \\
\hline
\end{tabular}

Note: The delivery date includes day, month and year. For the purpose of this table observations are aggregated by month and year.

Table 4. Descriptive statistics

\begin{tabular}{|c|c|c|c|c|c|c|}
\hline \multirow[b]{2}{*}{ Definition } & \multicolumn{3}{|c|}{ October 2006} & \multicolumn{3}{|c|}{ October 2009} \\
\hline & Obs & Mean & Std. Dev. & Obs & Mean & Std. Dev. \\
\hline Standardised reading score & 2057 & 0.00 & 1.00 & 2057 & 0.00 & 1.00 \\
\hline Standardised math score & 2080 & 0.00 & 1.00 & 2080 & 0.00 & 1.00 \\
\hline Days exposed to the program up to the date of the reading test, normalized to years & 2057 & 0.00 & 0.00 & 2057 & 0.71 & 0.51 \\
\hline Days exposed to the program up to the date of the math test, normalized to years & 2080 & 0.00 & 0.00 & 2080 & 0.72 & 0.51 \\
\hline Male; 0 otherwise & 2080 & 0.52 & 0.50 & 2080 & 0.52 & 0.50 \\
\hline Mother's education: Did not finish primary school; 0 otherwise & 2080 & 0.11 & 0.31 & 2080 & 0.08 & 0.28 \\
\hline Mothers' education maximum level completed: Primary school; 0 otherwise & 2080 & 0.43 & 0.50 & 2080 & 0.42 & 0.49 \\
\hline Mothers' education maximum level completed: Junior high (9 years of schooling); 0 otherwise & 2080 & 0.21 & 0.41 & 2080 & 0.25 & 0.43 \\
\hline Mothers' education maximum level completed: Secondary school or College; 0 otherwise & 2080 & 0.13 & 0.33 & 2080 & 0.14 & 0.35 \\
\hline Information about mother's education is missing; 0 otherwise & 2080 & 0.12 & 0.32 & 2080 & 0.11 & 0.32 \\
\hline Number of persons living at home; 0 if information is missing & 2080 & 4.07 & 2.92 & 2080 & 4.59 & 2.39 \\
\hline Information about persons living at home is missing; 0 otherwise & 2080 & 0.24 & 0.43 & 2080 & 0.10 & 0.30 \\
\hline Number of primary schools that participated in the evaluation & \multicolumn{3}{|c|}{90} & \multicolumn{3}{|c|}{90} \\
\hline
\end{tabular}

Note: Estimates also include variables regarding number of books at home, number of rooms, access to drinkable water, phone, cable, dvd, microwave, washing machine, dishwasher, internet and computer at home. Also information regarding whether the student works and is paid for that. For those whose information on number of persons in the house is missing the variable persons has been recoded to 0 . 
Table 5. Individual fixed effects (2006-2009).

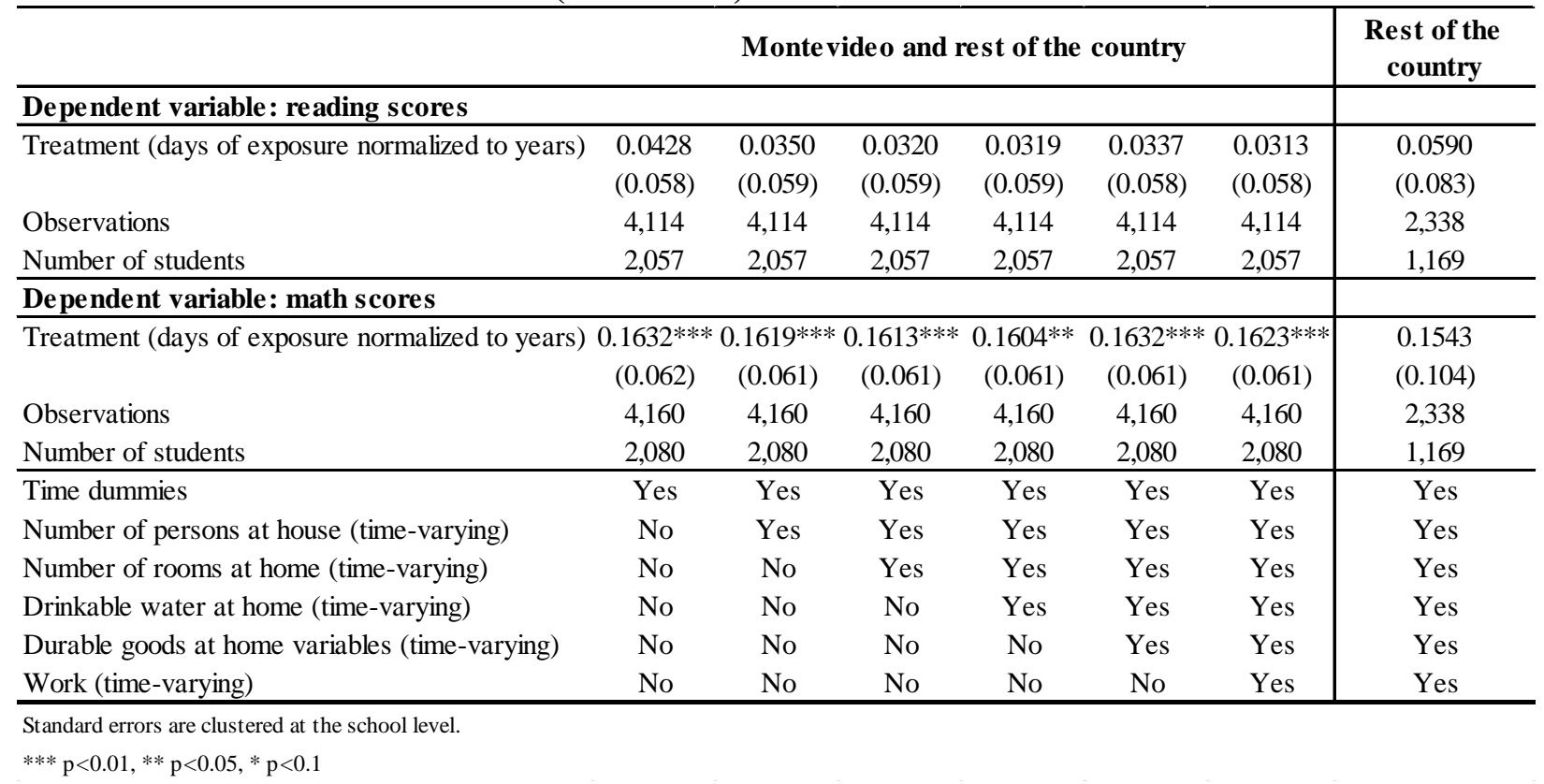

Table 6. Testing for the importance of regional changes across time in seniority with school fixed effects

\begin{tabular}{lc}
$\begin{array}{l}\text { Dependent variable: seniority (\% teachers } \\
\text { with less than } 5 \text { years of experience) }\end{array}$ & 2005-2006-2007 \\
\hline Montevideo*Year 2006 & -1.252 \\
& $(1.287)$ \\
Montevideo*Year 2007 & $-4.999 * * *$ \\
& $(1.427)$ \\
Observations & 6,551 \\
Number of schools & 2,340 \\
\hline Time dummies & Yes \\
School fixed effects & Yes \\
\hline
\end{tabular}

Source: own estimates using Monitor Educativo (ANEP).

Standard errors are clustered at the school level.

$* * * \mathrm{p}<0.01, * * \mathrm{p}<0.05, * \mathrm{p}<0.1$ 
Table 7. Individual fixed effects including school-time dummy or Montevideo-time dummy (2006-2009)

\begin{tabular}{lccccccc}
\hline Dependent variable: reading scores & & & & & & \\
\hline Treatment (days of exposure normalized to years) & -0.0544 & -0.0142 & 0.0104 & 0.0029 & -0.0008 & -0.0027 & -0.0664 \\
& $(0.413)$ & $(0.410)$ & $(0.398)$ & $(0.398)$ & $(0.406)$ & $(0.398)$ & $(0.101)$ \\
Observations & 4,114 & 4,114 & 4,114 & 4,114 & 4,114 & 4,114 & 4,114 \\
Number of students & 2,057 & 2,057 & 2,057 & 2,057 & 2,057 & 2,057 & 2,057 \\
\hline Dependent variable: math scores & & & & & & & \\
\hline Treatment (days of exposure normalized to years) & -0.1658 & -0.1561 & -0.1582 & -0.1620 & -0.1513 & -0.1601 & 0.0394 \\
& $(0.353)$ & $(0.359)$ & $(0.353)$ & $(0.355)$ & $(0.355)$ & $(0.353)$ & $(0.094)$ \\
Observations & 4,160 & 4,160 & 4,160 & 4,160 & 4,160 & 4,160 & 4,160 \\
Number of students & 2,080 & 2,080 & 2,080 & 2,080 & 2,080 & 2,080 & 2,080 \\
\hline Time dummies & Yes & Yes & Yes & Yes & Yes & Yes & Yes \\
School-time dummies & Yes & Yes & Yes & Yes & Yes & Yes & No \\
Montevideo-time dummy & No & No & No & No & No & No & Yes \\
Number of persons at house (time-varying) & No & Yes & Yes & Yes & Yes & Yes & Yes \\
Number of rooms at home (time-varying) & No & No & Yes & Yes & Yes & Yes & Yes \\
Drinkable water at home (time-varying) & No & No & No & Yes & Yes & Yes & Yes \\
Durable goods at home variables (time-varying) & No & No & No & No & Yes & Yes & Yes \\
Work (time-varying) & No & No & No & No & No & Yes & Yes \\
\hline
\end{tabular}

Standard errors are clustered at the school level.

$* * * \mathrm{p}<0.01, * * \mathrm{p}<0.05, * \mathrm{p}<0.1$

Table 8. Exploiting solely between school variation

\begin{tabular}{l|cc|c}
\hline & \multicolumn{2}{|c|}{$\begin{array}{c}\text { Monte video and the } \\
\text { rest of the country }\end{array}$} & $\begin{array}{c}\text { Excluding } \\
\text { Montevideo }\end{array}$ \\
\hline Dependent variable : reading scores & & & \\
\hline Treatment (days of exposure normalized to years) & 0.0879 & -0.0124 & 0.0496 \\
Observations & $(0.058)$ & $(0.103)$ & $(0.118)$ \\
Number of schools & 180 & 180 & 120 \\
\hline Dependent variable: math scores & 90 & 90 & 60 \\
\hline Treatment (days of exposure normalized to years) & & & \\
& $0.1344^{*}$ & -0.0604 & -0.0174 \\
Observations & $(0.069)$ & $(0.116)$ & $(0.146)$ \\
Number of schools & 180 & 180 & 120 \\
Time dummies & 90 & 90 & 60 \\
Montevideo-time dummy & Yes & Yes & Yes \\
Number of persons at house (time-varying) & No & Yes & No \\
Number of rooms at home (time-varying) & Yes & Yes & Yes \\
Drinkable water at home (time-varying) & Yes & Yes & Yes \\
Durable goods at home variables (time-varying) & Yes & Yes & Yes \\
Work (time-varying) & Yes & Yes & Yes \\
\hline
\end{tabular}

Standard errors are clustered at the school level.

$* * * \mathrm{p}<0.01, * * \mathrm{p}<0.05, * \mathrm{p}<0.1$ 
Table 9. Heterogeneous effects by mother education

\begin{tabular}{lcc}
\hline Dependent variable: & Reading & Math \\
\hline & & \\
Treatment (years) & -0.0172 & -0.0980 \\
& $(0.394)$ & $(0.366)$ \\
Treatment (years) * Mom's education: Primary school & -0.0985 & -0.1146 \\
& $(0.083)$ & $(0.090)$ \\
Treatment (years) * Mom's education: Junior high & 0.0134 & -0.0181 \\
& $(0.071)$ & $(0.081)$ \\
Treatment (years) * Mom's education: Secondary school or College & 0.0957 & -0.1281 \\
& $(0.093)$ & $(0.090)$ \\
Treatment (years) * Mom's education is missing & 0.0368 & -0.1147 \\
& $(0.089)$ & $(0.109)$ \\
Observations & 4,114 & 4,160 \\
Individuals & 2,057 & 2,080 \\
\hline Time dummies & Yes & Yes \\
School dummies & Yes & Yes \\
School trend dummies & Yes & Yes \\
Number of rooms at home (time-varying) & Yes & Yes \\
Drinkable water at home (time-varying) & Yes & Yes \\
Durable goods at home variables (time-varying) & Yes & Yes \\
Work (time-varying) & Yes & Yes \\
\hline
\end{tabular}

Standard errors are clustered at the school level.

*** $\mathrm{p}<0.01,{ }^{* *} \mathrm{p}<0.05,{ }^{*} \mathrm{p}<0.1$

Table 10. Frequency of laptop use in class (October 2009)

\begin{tabular}{lcc}
\hline & $\begin{array}{l}\text { In your reading classes: } \\
\text { How often do you use } \\
\text { the laptop? }\end{array}$ & $\begin{array}{l}\text { In your math classes: } \\
\text { How often do you use } \\
\text { the laptop? }\end{array}$ \\
\hline Every day or almost every day & $37.6 \%$ & $26.0 \%$ \\
One up to three times per week & $38.0 \%$ & $25.4 \%$ \\
Less than once per week & $24.3 \%$ & $48.6 \%$ \\
\hline
\end{tabular}

Source: V Evaluación Nacional de Aprendizajes, ANEP 2009, weighted.

Table 11. Main laptop use in class and at home (October 2009)

\begin{tabular}{lcc}
\hline & School & Home \\
\hline Search information in the internet & $67.5 \%$ & $40.1 \%$ \\
Write a text & $13.1 \%$ & $5.0 \%$ \\
Spreadsheet & $0.2 \%$ & $0.0 \%$ \\
Calculator & $0.8 \%$ & $0.2 \%$ \\
Send emails & $1.3 \%$ & $1.9 \%$ \\
Play & $11.5 \%$ & $38.6 \%$ \\
Chat & $2.7 \%$ & $8.6 \%$ \\
Other & $2.9 \%$ & $5.6 \%$ \\
\hline
\end{tabular}

Source: V Evaluación Nacional de Aprendizajes, ANEP 2009, weighted. 